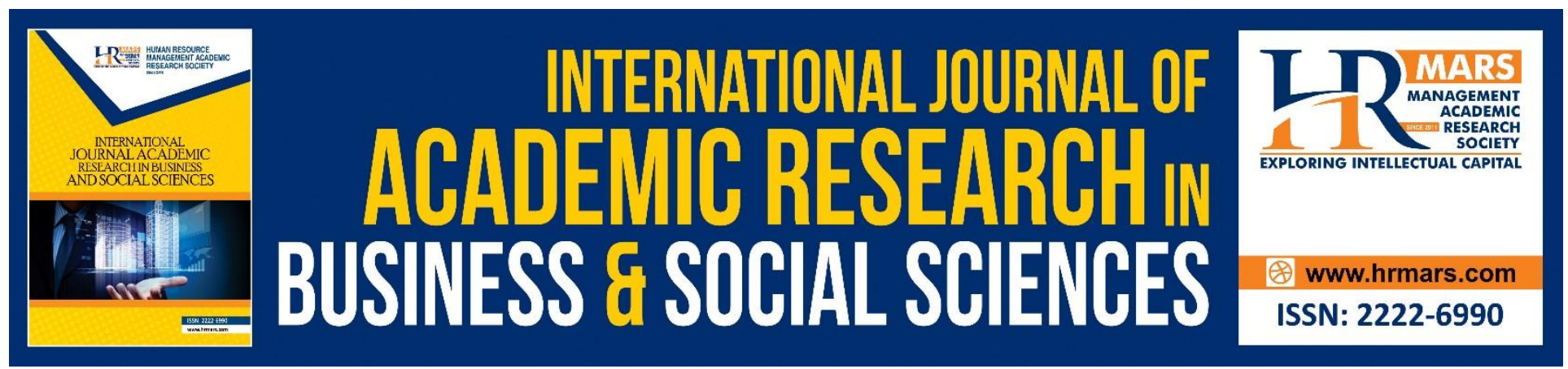

\title{
A Study on Consumer Attitude towards Shariah-Compliant Hotel: Assessing on Halal Image and Religiosity
}

Fadzilah Mohd Shariff, Nor Fatanah Mokhtar, Khairunnisa Mohamad Abdullah, Wan Ahmad Nasroun Wan Salman

To Link this Article: http://dx.doi.org/10.6007/IJARBSS/v11-i13/8479

DOI:10.6007/IJARBSS/v11-i13/8479

Received: 03 November 2020, Revised: 01 December 2020, Accepted: 24 December 2020

Published Online: 22 January 2021

In-Text Citation: (Shariff et al., 2021)

To Cite this Article: Shariff, F. M., Mokhtar, N. F., Abdullah, K. M., \& Salman, W. A. N. W. (2021). A Study on Consumer Attitude towards Shariah-Compliant Hotel: Assessing on Halal Image and Religiosity. International Journal of Academic Research in Business and Social Sciences, 11(13), 1-11.

\section{Copyright: (c) 2021 The Author(s)}

Published by Human Resource Management Academic Research Society (www.hrmars.com)

This article is published under the Creative Commons Attribution (CC BY 4.0) license. Anyone may reproduce, distribute, translate and create derivative works of this article (for both commercial and non-commercial purposes), subject to full attribution to the original publication and authors. The full terms of this license may be seen

at: http://creativecommons.org/licences/by/4.0/legalcode

Special Issue: Beyond 2021 and COVID-19 - New Perspective in the Hospitality \& Tourism Industry, 2021, Pg. 1 - 11

Full Terms \& Conditions of access and use can be found at http://hrmars.com/index.php/pages/detail/publication-ethics 


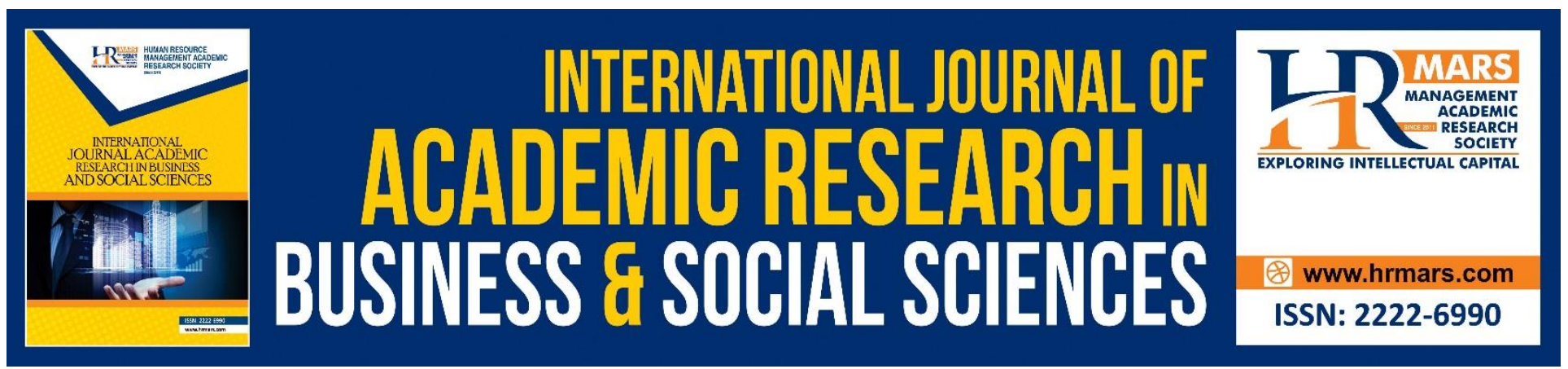

\title{
A Study on Consumer Attitude towards Shariah- Compliant Hotel: Assessing on Halal Image and Religiosity
}

\section{Fadzilah Mohd Shariff, Nor Fatanah Mokhtar, Khairunnisa Mohamad Abdullah, Wan Ahmad Nasroun Wan Salman}

Faculty of Hotel and Tourism Management, Universiti Teknologi MARA Cawangan Selangor, Puncak Alam Campus, 43200, Selangor, Malaysia

\begin{abstract}
This study aims to examine the relationship between halal image and religiosity on the attitude of consumers towards purchasing Shariah-compliant hotel services in Klang Valley. Data collected using the survey method and 420 usable questionnaires were received from the respondents. A regression analysis was conducted to test the hypotheses. The results of the study showed that the proposed halal image, religiosity, and consumer attitudes variables have a significant effect on customer purchase intention towards the Shariah-compliant hotel. The result also shows that there is a significant relationship between attitude and customer purchase intention towards Shariahcompliant hotels. The result of this study would be able to assist the hotel managers in decision making, particularly in selecting the right image for Shariah-compliant hotels.
\end{abstract}

Keywords: Attitude, Halal Image, Purchased Intentions, Religiosity.

\section{Introduction}

The concept of Shariah-compliant hotel has been added to the Islamic hospitality and tourism in Malaysia. A lot of effort and attention are paid toward the development of hotels that are Shariah-compliant (Salleh et al., 2014). Shariah-compliant hotel is widely referred to as a hotel that provide customers with services that are created as well as delivered following Shariah rules and principles (Haque, Azam, \& Chowdhury, 2019). Shariah is an Arabic word means the path to be followed (Hyder, 2017). Shariah governs every aspect of daily life and provides a moral and legal framework for Muslim.

Religion has been continuously proven to be a key factor that impacts the consumption behaviour of individuals (Muhamad \& Mizerski, 2010). The same applies to the hotel industry as Muslim consumers demand hotels that provide facilities that comply with Shariah principles (Haque 
et al., 2019). With the increasing number of Muslim tourists making tourism businesses want to develop and promote products that correspond to the needs of their Muslim consumers and understand their behaviour such as products related to the hospitality and services (Shafaei \& Mohamed, 2014).

For such reasons, Shariah-compliant hotels have been represented as a crucial aspect of Islamic tourism. Therefore, gaining a clear understanding of the factors that can affect the behavior of purchasing Muslim consumers against Shariah-compliant hotel is very important because it will allow the marketers to acquire the necessary knowledge, develop appropriate images and emphasize the different aspects that are important for serving Muslim consumers. By taking into consideration the current needs as well as trends, this study aims to explore the factors that may affect consumer attitude purchase intention towards Shariah-compliant hotels.

\section{Literature Review}

\section{Halal Image and Purchase Intention}

The word Halal is derived from the verb 'Halla', which means lawful, legal, licit, legitimate, and permitted for Muslims (Jallad, 2008). In reality, Halal is a spiritual need of Muslim consumers (Alserhan, 2010) that plays a vital role in their life by sending them a signal to purchase and consume permissible products (Rajagopal et al. 2011; Shafie \& Othman, 2006). In marketing, halal is used to understand the rights of products and services with principles in the Quran and Syariah (Suki and Salleh, 2016; Lada, Tanakinjal, \& Amin, 2009). From an Islamic perspective, halal image can reflect the perception of consumers especially Muslims against the characteristics of the brand maintaining in their memory and will then influence the manufacture of their purchasing decisions (Suki \& Salleh, 2016). Likewise, rights in Islam are taken by consumers based on the reason that Islamic values have a profound impact on the social ethics of their society, especially Muslims and their consumption patterns (Khraim, 2010). Literature proves that there is likelihood of consumers to have the desire to purchase from manufacturing with halal images and withstand non-halal images, and consumers' intention to patronizing halal stores is also based on halal image decisions (Suki \& Salleh, 2016).

\section{Religiosity and Purchase Intention}

Religiosity demonstrates one's belief in the overall accuracy and quality of truth built in the teachings and religious scriptures (Moschis \& Ong, 2011). According to Mokhlis and Sparks (2007), religious commitments found to have significant influence on a person, cognitively, and behaviorally. Religious commitments have been found to be the main drivers of both Muslims as well as attitudes, behaviors, lifestyles of non-Muslim consumers as well as usage habits (Salman \& Siddiqui, 2011 and Mukhtar \& Butt, 2012). They further indicated that, religious commitment in the form of the basis of the consumption choice for consumers along with Muslim and non-Muslim, and the religious commitment helps them choose the right path in their decision making and their lives. Religion also plays an important role in the field of consumer behavior (Sun, Goh, Fam, \& Xue, 2012). According to Rehman and Shabbir (2010), religion will help consumers especially Muslims, in terms of making differentiation between permissible and non-permissible products. The consumers' behavior and attitude toward selection, purchase, and consumption of the products and services depend on their religious principles (Khraim, 2010). This statement is supported by Said, Hassan, Musa, and Rahman 
(2015) that religious commitment has relationships with halal consumption. It was confirmed by Jamal and Sharifuddin (2015) and Borzooei and Asgari (2013) that consumers' religiosity is essential to the formation of the consumers' intention to purchase the product and services.

\section{Attitudes and Purchase Intention}

An attitude is considered an encouraging or unfavorable assessment of an individual's behavior (Ajzen, 1991). He has further added that peoples' attitude can be understood by taking into consideration the behavioral beliefs and connecting the respected behaviors to different outcomes and attributes. Ajzen and Fishbein (2005) stated that individuals formulate their attitude based on their beliefs about the outcome of conducting certain behaviors. He further explained that the outcome of the behavior can either be seen as a behavioral belief, the expectations of a person's outcome as well as the costs and benefits of implementing their behaviour. Previous studies indicated that the attitude has a significant relationship on purchase intention, which is drawn from consumers' favorable attitude towards halal products and services (Abd Rahman et al., 2015; Mukhtar \& Butt, 2012; Alam \& Sayuti, 2011). Similar findings were also uncovered by Lada et al. (2009) that Muslim consumers' intention of purchasing halal food products is predicted by their attitude toward the respective product. Majority of the findings of past literature demonstrate that attitude is an important aspect that is strongly associated with Muslim consumers' purchase intention. On this basis, the following framework was proposed.

\section{Conceptual Framework}

This study is designed to examine the consumer attitudes towards Shariah-compliant hotel. A modified Ajzen Theory of Planned Behavior (Fishbein and Ajzen, 1975) was adopted. Based on the conceptual framework, there are two independent variables proposed for the study which are halal image and religiosity. The following hypotheses were proposed:

$\mathrm{H}_{1}$ : There is a positive relationship between halal image and purchase intention towards Shariah-compliant hotels.

$\mathrm{H}_{2}$ : There is a positive relationship between religiosity and purchase intention towards Shariah-compliant hotels.

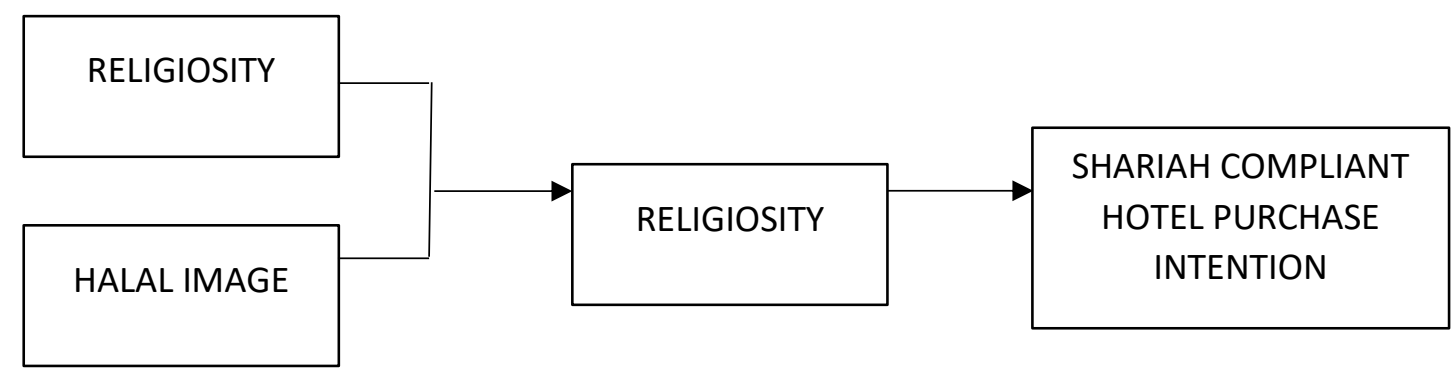

Figure 1: A Proposed Framework on The Relationship between Religiosity, Halal Image and Attitude on Shariah-compliant Hotel Purchase Intention 


\section{Methodology}

The study adopts a quantitative research method to examine the effects of halal image, religiosity, and attitude among Muslim consumers on their purchase intention of Shariah-compliant hotels in Klang Valley, Malaysia. A total of 42 hotels have been recognized to be under the MuslimFriendly Accommodation Recognition (MFAR) scheme (Yusof, 2020). The major reason for choosing Klang Valley lies in the fact that it consists of majority of the tourist destinations in the nation. Random sampling method was adopted as it has the least bias and offers the most generalizability (Sekaran, 2005). Data were gathered from 420 participants through a self-administered questionnaire. The questionnaire was designed in a statement format and then tested for reliability and validity. A five-point Likert-type scale was used as the measurement of scale where 1 represented strongly disagree and 5 denoted strongly agree. The questionnaire was divided into four parts. The first part gathers the demographic profile of the participating respondents and the second part consists of statements on the Halal Image. The third part investigates the respondents' level of religiosity and the fourth part is on consumer attitudes towards purchase intention. All the measures used in the study were adapted from existing studies related to Shariah-compliant Hotels. The Statistical Package for Social Science (SPSS) version 26 was employed for analyzing the data. Table 1 depicts the sources from where the items have been adapted. The reliability test for all of the variables has been conducted to determine the reliability of the instrument.

Table 1: Reliability Test

\begin{tabular}{|c|c|c|}
\hline Component & $\begin{array}{l}\text { Cronbach's } \\
\text { Alpha }\end{array}$ & Sources \\
\hline Halal Image & .856 & $\begin{array}{l}\text { Awan et al. (2015); Yunus } \\
\text { 015) }\end{array}$ \\
\hline Religiosity & .913 & Rehman and Shabbir \\
\hline Purchase Intention & .919 & $\begin{array}{l}\text { Haque et al (2015); Lada } \\
\text { 009) }\end{array}$ \\
\hline
\end{tabular}

\section{Result and Analysis}

Purchase intention can be described as a key antecedent that creates consumers' purchase behavior (Nguyen et al., 2010). Prior studies stated that to understand consumers' purchase behavior was through what affected their intentions (Ghalandari \& Norouzi, 2012). Many factors influence the intention of the consumer. This study focuses on assessing the consumer purchase intention by looking at the two variables which are halal image and religiosity. The discussion on the study findings is on demographic, halal image, religiosity, consumer purchase intention, and the analysis of the relationship.

\section{Demographic}

The demographic background for the total number of 420 respondents is presented in Table 2. Most of the respondent's ages are between 20 to 30 years old (66.5\%), 31 to 40 years old (29.8\%), and 41 to 55 years old (3.8\%). In terms of gender distribution, females contributed to $55.7 \%$ whereas 
INTERNATIONAL JOURNAL OF ACADEMIC RESEARCH IN BUSINESS AND SOCIAL SCIENCES

Vol. 11, No. 13, Beyond 2021 and COVID-19 - New Perspective in the Hospitality \& Tourism Industry. 2021, E-ISSN: 2222-6990 @ 2021 HRMARS

$44.3 \%$ of the respondents are males. $44.5 \%$ of the respondents were self-employed, $15 \%$ are civil servants, and $33.3 \%$ worked with private sectors.

Table 2: Demographic Profiles of the Respondents.

\begin{tabular}{|c|c|c|}
\hline Variables & Frequency & Percentage (\%) \\
\hline \multicolumn{3}{|l|}{ Gender } \\
\hline Male & 186 & 44.3 \\
\hline Female & 234 & 55.7 \\
\hline \multicolumn{3}{|l|}{ Age } \\
\hline 20 to 30 & 279 & 66.5 \\
\hline 31 to 40 & 125 & 29.8 \\
\hline 41 to 55 & 16 & 3.8 \\
\hline \multicolumn{3}{|l|}{ Race } \\
\hline Malay & 414 & 98.5 \\
\hline Chinese & 4 & 1.0 \\
\hline Indian & 0 & 0 \\
\hline Others & 2 & 0.5 \\
\hline \multicolumn{3}{|l|}{ Occupation } \\
\hline Self-employed & 187 & 44.5 \\
\hline Government & 63 & 15.0 \\
\hline Private & 140 & 33.3 \\
\hline Not Working & 30 & 7.2 \\
\hline & & $100 \%$ \\
\hline
\end{tabular}

\section{Halal Image}

The second part of the study is to measure the halal image towards Shariah-compliant hotels. Table 3 explains the five items that measure the halal image. The mean scores revealed that the respondents agree with each of the statement items. The highest mean score is 4.20 and a standard deviation of 0.542 for an item, "Shariah-compliant hotels is trustworthy about halal promises". The second highest is "Shariah-compliant hotels is the best benchmark for Halal commitments" with a mean score $(M=4.19)$ and a standard deviation of 0.535 . The third highest mean score is "Shariah-compliant Hotel has good Islamic entertainment and recreational facilities" with a mean score $(M=4.16)$ and a standard deviation of 0.636 . The fourth highest mean score is 4.16 with a standard deviation of 0.555 for item, "Shariah-compliant hotels are environment friendly". The fifth highest score is "Shariah-compliant Hotels addresses all my halal concerns" ( $M=4.15)$ with a standard deviation of 0.531 . This outcome shows that consumers agree that Shariah-compliant hotels can be trusted about halal promises but they less agree that Shariah-compliant hotels can be addressed as consumers' halal concerns. This shows that there is a significant relationship between halal image and purchase intention towards Shariah-compliant hotels. 
INTERNATIONAL JOURNAL OF ACADEMIC RESEARCH IN BUSINESS AND SOCIAL SCIENCES

Vol. 11, No. 13, Beyond 2021 and COVID-19 - New Perspective in the Hospitality \& Tourism Industry. 2021, E-ISSN: $2222-6990$ @ 2021 HRMARS

Table 3: Halal Image on Shariah-Compliant Hotel

\begin{tabular}{|c|c|c|c|c|c|c|c|c|c|c|}
\hline 0 & $\mathbf{N}$ & $\begin{array}{l}\text { Scal } \\
\text { e Items }\end{array}$ & & $\mathbf{N}$ & mum & mum & $\begin{array}{c}\text { ean } \\
1\end{array}$ & $\begin{array}{l}M \\
\text { (M }\end{array}$ & $\begin{array}{l}\text { td. } \\
\text { Deviatio } \\
\text { SD) }\end{array}$ & 1 \\
\hline . & 1 & $\begin{array}{l}\quad \text { Shari } \\
\text { ah-compliant } \\
\text { Hotels is the } \\
\text { best } \\
\text { benchmark } \\
\text { for halal } \\
\text { commitments. }\end{array}$ & 20 & 4 & 2 & 5 & 9 & 4.1 & 35 & .5 \\
\hline & 2 & $\begin{array}{l}\text { Shari } \\
\text { ah-compliant } \\
\text { Hotels } \\
\text { addresses all } \\
\text { my halal } \\
\text { concerns. }\end{array}$ & 20 & 4 & 2 & 5 & 5 & 4.1 & 31 & .5 \\
\hline & 3 & $\begin{array}{l}\text { Shari } \\
\text { ah-compliant } \\
\text { Hotels is } \\
\text { trustworthy } \\
\text { about halal } \\
\text { promises. }\end{array}$ & 20 & 4 & 3 & 5 & 0 & 4.2 & 42 & .5 \\
\hline & 4 & $\begin{array}{l}\text { Shari } \\
\text { ah-compliant } \\
\text { Hotels are } \\
\text { environment } \\
\text { friendly. }\end{array}$ & 20 & 4 & 2 & 5 & 6 & 4.1 & 55 & .5 \\
\hline & 5 & $\begin{array}{l}\text { Shari } \\
\text { ah-compliant } \\
\text { Hotel has } \\
\text { good Islamic } \\
\text { entertainment } \\
\text { and } \\
\text { recreational } \\
\text { facilities. }\end{array}$ & 20 & 4 & 2 & 5 & 6 & 4.1 & 36 & .6 \\
\hline
\end{tabular}

\section{Religiosity}

The third part of the study measures consumer purchase intention which is influenced by religiosity. The results show that the respondents agree with each of the statements in the questionnaire. The highest mean score at 4.61 is "Religion is especially important to me", "My religious faith is extremely important to me" with a mean score of 4.58. The respondents seem to agree with "Religious beliefs influence all my dealings in life" with a mean score $(M=4.53)$. The results also revealed that respondents feel that they can practice religion openly while traveling. Purchasing halal products and 
services are socially accepted. This implies that the religious belief will influence consumer's decisionmaking in choosing a Shariah-compliant Hotel when traveling. This shows that there is a significant relationship between religiosity and consumer purchase intention towards Shariah-compliant hotels.

Table 4: Religiosity on Shariah-Compliant Hotel

\begin{tabular}{|c|c|c|c|c|c|c|c|c|c|}
\hline 0 & $\mathbf{N}$ & $\begin{array}{l}\text { Scale } \\
\text { Items }\end{array}$ & & $\mathbf{N}$ & mum & $\begin{array}{l}\text { Maxi } \\
\text { mum }\end{array}$ & $\begin{array}{l}\text { ean } \\
\text { M) }\end{array}$ & $M$ & $\begin{array}{c}\text { td. }^{\text {S }} \\
\text { Deviation } \\
\text { SD) }\end{array}$ \\
\hline$\cdot$ & & \begin{tabular}{l}
\multicolumn{1}{c}{ My } \\
religious faith \\
is extremely \\
important to \\
me.
\end{tabular} & 20 & 4 & 3 & 5 & 58 & 4. & 557 \\
\hline$\cdot$ & 2 & $\begin{array}{l}\quad \text { I feel I } \\
\text { can practice } \\
\text { my religions } \\
\text { openly while } \\
\text { traveling. }\end{array}$ & 20 & 4 & 3 & 5 & 43 & 4. & $533^{\circ}$ \\
\hline$\cdot$ & 3 & $\begin{array}{l}\text { Religi } \\
\text { ous beliefs } \\
\text { influence all } \\
\text { my dealings in } \\
\text { life. }\end{array}$ & 20 & 4 & 3 & 5 & 53 & 4. & 567 \\
\hline$\cdot$ & 4 & $\begin{array}{l}\text { Religi } \\
\text { on is especially } \\
\text { important to } \\
\text { me. }\end{array}$ & 20 & 4 & 2 & 5 & 61 & 4. & 536 \\
\hline$\cdot$ & 5 & $\begin{array}{l}\qquad \text { Purch } \\
\text { asing Halal } \\
\text { products and } \\
\text { services has } \\
\text { more social } \\
\text { and family } \\
\text { acceptance. }\end{array}$ & 20 & 4 & 2 & 5 & 40 & 4. & 571 \\
\hline
\end{tabular}

\section{Correlation Analysis}

Correlation analysis has been conducted in this study to measure the strength of the linear relationship between variables. The results show that halal image has a strong significant relationship with purchase intention which is more than 0.5 . Thus, religiosity shows a moderate relationship with purchase intention which is less than 0.5. Table 5 represents the correlation coefficient between the independent and dependent variables. 
INTERNATIONAL JOURNAL OF ACADEMIC RESEARCH IN BUSINESS AND SOCIAL SCIENCES

Vol. 11, No. 13, Beyond 2021 and COVID-19 - New Perspective in the Hospitality \& Tourism Industry. 2021, E-ISSN: $2222-6990$ ๑ 2021 HRMARS

Table 5: Pearson Correlation Matrix for Study Variables

\begin{tabular}{cccc}
\hline Dimensions & $\begin{array}{c}\text { Test of } \\
\text { Significant }\end{array}$ & $\begin{array}{c}\text { Student } \\
\text { Satisfaction }\end{array}$ & $\begin{array}{c}\text { Correlation } \\
\text { Coefficient Indicator }\end{array}$ \\
& Pearson & $.743^{* *}$ & Strong \\
\hline Halal Image & Correlation Sig. (2-tailed) & .000 & \\
& $\mathrm{~N}$ & 420 & Moderate \\
& Pearson & $.476^{* *}$ & \\
\hline Religiosity & Correlation Sig. (2-tailed) & .000 & \\
& $\mathrm{~N}$ & 420 & \\
& &
\end{tabular}

Correlation is significant at the 0.01 level (2-tailed)

Table 6: Summary of Hypotheses Testing

\begin{tabular}{ccc}
\hline $\mathbf{H}_{\mathbf{x}}$ & Hypothesis & Finding \\
\hline $\mathrm{H}_{1}$ & There is a positive relationship between & Supported \\
& halal image and purchase & Supported \\
\hline $\mathrm{H}_{2}$ & There is a positive relationship between & \\
& religiosity and purchase intention & \\
\hline
\end{tabular}

\section{Conclusion}

This paper focuses on assessing halal image and religiosity on consumer purchase intention towards Shariah-compliant hotels. The results indicate that halal images have a significant relationship with consumer purchase intention towards the Shariah-compliant hotel. This result has in common with a previous study where marketers need more focus on creating more halal images in their establishment (Lada et al., 2009; Suki and Salleh, 2016). The halal image gives positive consumer perceptions, especially when using products and services during their stay in Shariahcompliant hotels. Although the study shows positive relationships between halal image, religiosity, and purchase intention, hoteliers still need to improve their product and services in strategizing the business in invention and innovation towards consumer halal perceptions. Hoteliers may also need to improve and avoid any products and services that may offend the religious belief of consumers. In conclusion, the outcome of this study will give additional information to Shariah-compliant hotels especially hotels in Klang Valley. The hotels can improve their products and services according to their customer needs and wants. Further research on awareness and readiness of consumer acceptance on Shariah-compliant hotels and services are encouraged.

\section{Corresponding Author}

Fadzilah Mohd Shariff

Faculty of Hotel and Tourism Management, Universiti Teknologi MARA Cawangan Selangor, Puncak Alam Campus, 42300, Selangor Malaysia.

Email: fshariff@uitm.edu.my 


\section{References}

Abd Rahman, A., Asrarhaghighi, E., and Ab Rahman, S. (2015). Consumers and halal cosmetic products: Knowledge, religiosity, attitude and intention. Journal of Is/amic Marketing 6(1), 148163.

Ajzen, I. (1991) 'The theory of planned behaviour'. Organizational Behaviour and Human Decision Processes, 50(2), 179-211.

Ajzen, I., and Fishbein, M. (2005). The influence of attitudes on behaviour. The Handbook of Attitudes, Vol. 173, No. 221, pp.173-222, Lawrence Erlbaum Associates Publishers, New Jersey.

Alam, S., and Sayuti, N. (2011). Applying the Theory of Planned Behavior (TPB) in halal food purchasing". International Journal of Commerce and Management, 21(1), 8- 20.

Alserhan, B. A. (2010). Islamic branding: A conceptualization of related terms. Brand Management, 18(1), 34-49.

Borzooei, M., and Asgari, M. (2013). The Halal brand personality and its effect on purchase intention. Interdisciplinary Journal of Contemporary Research in Business, 5(3), 481-491.

Fishbein, M., and Ajzen, I. (1975). Belief, Attitude. Intention and Behavior: An Introduction to Theory and Research. Reading, MA: Addison-Wesley

Ghalandari, K., and Norouzi, A. (2012). The effect of country of origin on purchase intention: The role of product knowledge. Research Journal of Applied Sciences, Engineering and Technology, 4(9), 1166-1171.

Haque, A., Azam, S. M. F., and Chowdhury, N. A. (2019) 'Factors affecting purchase behaviour of Shariah compliant hotels: a study from Muslim consumers' perspective'. Int. Journal Islamic Marketing and Branding, 4(2), 104-123.

Haque, A., Chowdhury, N. A., Yasmin, F., \& Tarofder, A. K. (2019). Muslim Consumers' Purchase Behavior Towards Shariah Compliant Hotels in Malaysia. Vidyodaya Journal of Management, 5(1), 121-138.

Gulam, H. (2017), The application of Shariah (Islamic Law) in some different countries and its implications. Shariah Journal, 24(2), 321-340.

Jallad, N. A. (2008). The concepts of al-halal and al-haram in the Arab-Muslim culture: a translational and lexicographical study. Language Design, 10, 77-86.

Jamal, J., and Sharifuddin, J. (2015). Perceived value and perceived usefulness of halal labeling: The role of religion and culture. Journal of Business Research, 68(5), 933-941.

Khraim, H. (2010). Measuring religiosity in consumer research from an Islamic perspective. Journal of Economic and Administrative Sciences, 52-78.

Lada, S., Tanakinjal, G. H., and Amin, H. (2009). Predicting intention to choose halal products using theory of reasoned action. International Journal of Islamic and Middle Eastern Finance and Management, 2(1), 66-76.

Mokhlis, S., and Sparks, L. (2007). Consumer religiosity and shopping behaviour in Kuala Lumpur. Malaysian Management Journal, 11(1/2), 87-101.

Moschis, G. P., and Ong, F. S. (2011). Religiosity and consumer behavior of older adults: a study of subcultural influences in Malaysia. Journal of Consumer Behaviour, 108-120.

Muhamad, N., and Mizerski, D. (2010) 'The constructs mediating religions' influence on buyers and consumers'. Journal of Islamic Marketing, 1(2), 124-135. 
Mukhtar, A., and Butt, M. (2012). Intention to choose halal products: The role of religiosity. Journal of Islamic Marketing, 3(2), 108-120.

Nguyen, T. D., Nguyen, T., \& Barrett, N. J. (2010). Consumer ethnocentrism, cultural sensitivity, and intention to purchase local products evidence from Vietnam. Journal of consumer behaviour, 7(1), 88-100.

Rajagopal, S., Ramanan, S., Visvanathan, R., \& Satapathy, S. (2011). Halal certification: implication for marketers in UAE. Journal of Islamic Marketing, 2(2), 138-153.

Rehman, A. U., and Shabbir, S. M. (2010). The relationship between religiosity and new product adoption. Journal of Islamic Marketing, 63-69.

Said, M., Hassan, F., Musa, R., and Rahman, N. A. (2015). Assessing consumers' perception, knowledge and religiosity on Malaysia's Halal Food Products. Procedia-Social and Behavioral Sciences, 120-128.

Salleh, N. Z. M., Hamid, A. B. A., Hashim, N. H., and Omain, S. Z. (2014) 'The practice of Shariahcompliant hotel in Malaysia'. International Journal of Trade, Economics and Finance, 5(1), 2639.

Salman, F., and Siddiqui, K. (2011). An exploratory study for measuring consumers awareness and perceptions towards halal food in Pakistan. Interdisciplinary Journal of Contemporary Research in Business, 3(2), 639-652.

Sekaran, U. (Ed.). (2005). Research Methods for Business: A Skill Building Approach (4th ed.): John Wiley \& Sons, Inc.

Shafie, S., \& Othman, N. (2006). Halal Certification: an international marketing issues and challenges. Journal of Marketing Research, (15), 565-575.

Shafaei, F., and Mohamed, B. (2014). Involvement and brand equity: a conceptual model for Muslim tourists. International Journal of Culture, Tourism and Hospitality Research, 54-67.

Suki, N. M., and Salleh, A. A. (2016). Does Halal image strengthen consumer intention to patronize Halal stores. Journal of Islamic Marketing, 81-98.

Sun, S., Goh, T., Fam, K. S., and Xue, Y. (2012). The influence of religion on Islamic mobile phone banking services adoption. Journal of Islamic Marketing, 3(1), 81-98.

Yusof, T. A. (2020). 42 hotels recognised as syariah-compliant to attract more Muslim tourists. NST. Retrieved from https://www.nst.com.my/news/nation/2020/09/621681 